\title{
Immunohistochemical expression of RANKL in oral giant cell lesions is predictive of aggressiveness
}

\section{Georgia MARTINI(a) \\ Diogo CAPELLA(a) \\ Elena Riet Correa RIVERO(b) \\ Rogério Oliveira GONDAK ${ }^{(b)}$}

(a) Universidade Federal de Santa Catarina UFSC, Postgraduate Program in Dentistry, Florianópolis, Santa Catarina, Brazil.

(b) Universidade Federal de Santa Catarina - UFSC, Department of Pathology, Florianópolis, Santa Catarina, Brazil.
Declaration of Interests: The authors certify that they have no commercial or associative interest that represents a conflict of interest in connection with the manuscript.

\section{Corresponding Author:}

Rogério Oliveira Gondak

E-mail: rogerio.gondak@ufsc.br

htpps://doi.org/10.1590/1807-3107bor-2018.vol32.0115

Submitted: February 23, 2018

Accepted for publication: August 21, 2018

Last revision: September 17, 2018

\begin{abstract}
The aim of this study was to evaluate the immunohistochemical expression of receptor activator of nuclear factor kappa-B ligand (RANKL) and of osteoprotegerin (OPG), important proteins correlated with osteoclastogenesis, in central giant cell lesions (CGCL) and peripheral giant cell lesions (PGCL) and to compare their expression with the histological and clinical parameters for quantification of multinucleated giant cells (MGC) and their nuclei, lesion size, and recurrences. Twenty cases of each lesion type were selected to quantify the number of MGCs and nuclei/ $\mathrm{mm}^{2}$ of connective tissue. The immunoreactivity of RANKL and OPG was expressed as a percentage of the marked area in the stroma. Clinical data were collected from pathoanatomical and medical reports. No statistical differences were found for the number of MGCs $(p=0.24)$ between PGCL and CGCL, but the number of nuclei within the MGCs was higher in CGCL $(p=0.01)$. RANKL expression was higher in CGCL than in PGCL $(p=0.04)$ and all recurrent lesions showed higher RANKL and OPG expressions than nonrecurrent lesions. We report higher RANKL expression and a greater number of nuclei in CGCL, which may explain the difference in clinical behaviour between these lesions and their pathogenesis.
\end{abstract}

Keywords: NF-kappa B; Osteoprotegerin; Immunohistochemistry.

\section{Introduction}

Central and peripheral giant cell lesions are benign lesions that affect the gnathic bones, although the aetiology and pathogenesis remain unclear. ${ }^{1}$ Peripheral giant cell lesion (PGCL) is described as a reactive lesion that only affects the gingiva and the alveolar ridge, manifesting as a red or purple nodule. This type of lesion can develop at any age; however, it is more common during the fifth and sixth decades of life. There is no sex predisposition and the lesions occur in both the maxilla and mandible., ${ }^{2,3}$ It is still unclear whether PGCL is a discrete entity or a peripheral variant of a central giant cell lesion (CGCL).

CGCL is a benign intraosseous lesion that mainly affects women aged under 30 years. CGCL tends to involve the mandible more than the maxilla and it is more common in the anterior region. ${ }^{4,5}$ The clinical behaviour ranges from a non-aggressive type, characterised by a slow-growing and painless lesion, to an aggressive type, characterised as a fast-growing lesion associated with pain, root resorption, and tooth displacement. ${ }^{6}$ 
Histologically, PGCL and CGCL are characterised by the presence of numerous multinucleated giant cells (MGCs) and mononuclear cells within a prominent and well-vascularised fibrous stroma, which may contain osteoid material., ${ }^{3,7}$ Although these two lesions present the same histological features, their clinical behaviour is distinct. Several researchers have attempted to explain the difference in clinical behaviour through cytomorphometric evaluation of MGCs and their nuclei, ${ }^{7}$ angiogenesis (CD34) and macrophage (CD68) markers, ${ }^{8}$ and expression of p53 (tumour suppressor gene), proliferating cell nuclear antigen (PCNA), $\mathrm{Ki}-67$ antigen (nuclear protein associated with cell proliferation), argyrophilic nucleolar organiser region (AgNOR), ${ }^{9}$ receptor activator of nuclear factor kappa-B (RANK), glucocorticoid receptor alpha (GRa), and calcitonin receptor (CTR). ${ }^{10}$

Investigations focused on the RANK/RANKL/OPG system in osteoclastogenesis have greatly contributed to knowledge about bone turnover processes. RANK, expressed in osteoclast precursors, binds to receptor activator of nuclear factor kappa-B ligand (RANKL), expressed in the membrane of osteoblasts and stromal cells, and plays an important role in osteoclast differentiation and activation. Osteoprotegerin (OPG) inhibits this process by binding to RANKL. Overexpression of RANK and/or RANKL has been observed in several bone diseases, such as osteoporosis, skeletal metastasis, and odontogenic tumours, ${ }^{11,12,13}$ and in conditions with higher osteolytic activity. ${ }^{14}$

The aim of this study was to evaluate the immunoexpression of RANKL and OPG in PGCL and CGCL and to determine the number of MGCs and their nuclei in order to further understand the clinical behaviour of these two lesions.

\section{Materials and methods}

\section{Tissue samples}

The archives from the Oral Pathology Laboratory at the Federal University of Santa Catarina for years 2006 to 2016 were retrospectively analysed. Twenty cases diagnosed with PGCL and 20 with CGCL were included in this study. Patients subjected to medical treatment or previous surgery were excluded. The data, including age, sex, size, anatomical site, and recurrences, were collected from pathoanatomical and medical reports.

This study was approved by the Human Research Ethics Committee of the Federal University of Santa Catarina (process \# 42095715.1.0000.0121).

\section{Quantification of giant cells and their nuclei}

The sections (5- $\mu \mathrm{m}$ thick) were stained with haematoxylin and eosin and then used for the histological evaluation. The sections were blindly analysed by two calibrated evaluators using a light microscope (Axiostar Plus; Carl Zeiss, Oberkochen, Germany) equipped with a digital camera (Canon Powershot A620; Cannon, Lake Success, NY, USA). Five fields were captured from each slide (400x magnification), selected from the central area of the lesion with a higher prevalence of MGCs. Quantification of MGCs and their respective nuclei was performed using Image J 1.45s software (National Institutes of Health, MD, USA). The number of MGCs and of their nuclei, adapted from Peacock et al., ${ }^{15}$ was counted.

\section{Immunohistochemistry}

For immunostaining, paraffin-embedded tissues were sliced into $3-\mu \mathrm{m}$ sections and mounted onto a series of glass slides containing 3-aminopropyltriethoxysilene (Sigma-Aldrich, St. Louis, USA). The sections were deparaffinised with xylene, followed by rehydration in decreasing concentrations of alcohol. Endogenous peroxidase activity was blocked by subsequently immersing slides in two baths containing $6 \%$ hydrogen peroxide diluted in methyl alcohol for 20 then 10 minutes at room temperature. Antigen retrieval was performed by immersing the slides in citrate buffer ( $\mathrm{pH}$ 6.0) at $96^{\circ} \mathrm{C}$ for 40 minutes. The slides were incubated with anti-RANKL (N-19, dilution 1:200; Santa Cruz Biotechnology, Santa Cruz, USA) and anti-OPG (N-20, dilution 1:200; Santa Cruz Biotechnology, Santa Cruz, USA) antibodies for 18 hours at 4 to $8^{\circ} \mathrm{C}$ in a humidified chamber. Thereafter, the slides were washed with phosphate-buffered saline (PBS) and incubated with 1:500 chicken anti-goat biotin conjugate antibody (Santa Cruz Biotechnology, Santa Cruz, USA). The reaction was visualised with a 
Vectastain $\mathrm{ABC}$ kit (Vector Laboratories, Burlingame, USA) and developed with DAB (Dako Cytomation, Glostrup, Denmark). Negative and positive controls were included during immunohistochemical reactions according to the manufacturer's recommendations.

\section{Immunohistochemical analysis}

Immunoexpression of RANKL and OPG was analysed using ImageJ $1.45 \mathrm{q}$ software (National Institutes of Health, USA). The analysis was performed for five high-power fields (400x) for each sample, captured with a camera (Cannon A620, Ōita, Japan) attached to a light microscope (Axiostar Plus, Carl Zeiss, Oberkochen, Germany). Hot spots without artefacts or with a high hemosiderin concentration were selected for immunohistochemical evaluation. The immunoreactivity of RANKL and OPG was characterised by brown cytoplasmic staining and the values were expressed as a percentage of the marked area in the stroma for each case. The RANKL to OPG ratio was also measured for each group.

\section{Statistical analysis}

The number of MGCs and of their nuclei, clinical parameters, and immunoexpression were statistically analysed by Fisher's exact test and Mann-Whitney test using SPSS software version 18.0 (SPSS Inc., Chicago, USA). Correlations between the parameters were evaluated using the Spearman's test. The results were expressed as mean \pm standard deviation (SD) and the level of statistical significance was $5 \%(p<0.05)$.

\section{Results}

\section{Clinical findings}

Among the 20 cases of PGCL, 12 (60\%) occurred in males, whereas 14 out of $20(70 \%)$ cases of CGCL occurred in females. The mean age of patients with PGCL and CGCL was $37 \pm 23.89$ and $24 \pm 17.67$ years, respectively. CGCL were larger and had more recurrences than PGCL. The mandible was more affected than the maxilla in both groups (Table 1).

\section{Histological findings}

There was no statistical difference in the number of MGCs per square millimetre between PGCL and
CGCL ( $p>0.05)$. However, the number of MGC nuclei was clearly higher in CGCL ( $p=0.01)$. The mean number of nuclei per MGC was 5.84 in PGCL and 7.21 in CGCL (Figures A and 1B, Table 1).

\section{Immunohistochemical analysis}

RANKL and OPG immunoreactivity was detected in MGC cytoplasm and membrane and in mononuclear cells, such as lymphocytes and endothelial cells. Immunohistochemical reactivity was observed in mononuclear cells in all cases; however, not all MGCs stained positive for RANK or OPG.

RANKL expression in CGCL was higher than in PGCL ( $p=0.04)$. There was no statistical difference between the two types of lesions for OPG expression $(P=0.09)$. Recurrent CGCL and PGCL had higher RANKL and OPG expressions than nonrecurrent lesions (Table 2). The RANKL to OPG ratio was not statistically different between the two groups (Figures C-F).

Table 1. Clinical, microscopic, and immunohistochemical findings in patients with central and peripheral giant cell lesions.

\begin{tabular}{lccc}
\hline Variable & PGCL $(\mathrm{n}=20)$ & $\mathrm{CGCL}(\mathrm{n}=20)$ & p-value \\
\hline Age (years \pm SD) & $37 \pm 23.89$ & $24 \pm 17.67$ & 0.168 \\
Sex & & & \\
$\quad$ Female & 8 & 14 & 0.057 \\
$\quad$ Male & 12 & 6 & \\
Anatomic site & & & \\
$\quad$ Mandible & 14 & 15 & $0.004^{*}$ \\
$\quad$ Maxilla & 6 & 5 & \\
Size (mm) & $17.4 \pm 10.1$ & $28.5 \pm 20.3$ & $0.037^{* *}$ \\
Recurrence (\%) & 5 & 15 & 0.302 \\
MGCs/mm & $39.3 \pm 19.1$ & $46.7 \pm 20.2$ & 0.245 \\
MGC nuclei/mm ${ }^{2}$ & $230.3 \pm 106.1$ & $336.7 \pm 144.3$ & $0.010^{* *}$ \\
RANKL (\%/area) & $4.9 \pm 3.1$ & $10.2 \pm 8.3$ & $0.042^{* *}$ \\
OPG (\%/area) & $4.6 \pm 2.7$ & $9.1 \pm 7.9$ & 0.091 \\
RANKL to OPG ratio & 1.16 & 1.76 & 0.330 \\
\hline PGCL: peripheral & & &
\end{tabular}

PGCL: peripheral giant cell lesion; CGCL: central giant cell lesion; SD: standard deviation; MGCs: Multinucleated giant cells; RANKL: Nuclear factor kappa-B ligand; OPG: Osteoprotegerin; *Fisher's exact test; ${ }^{* *}$ Mann-Whitney test. 
- Immunohistochemical expression of RANKL in oral giant cell lesions is predictive of aggressiveness
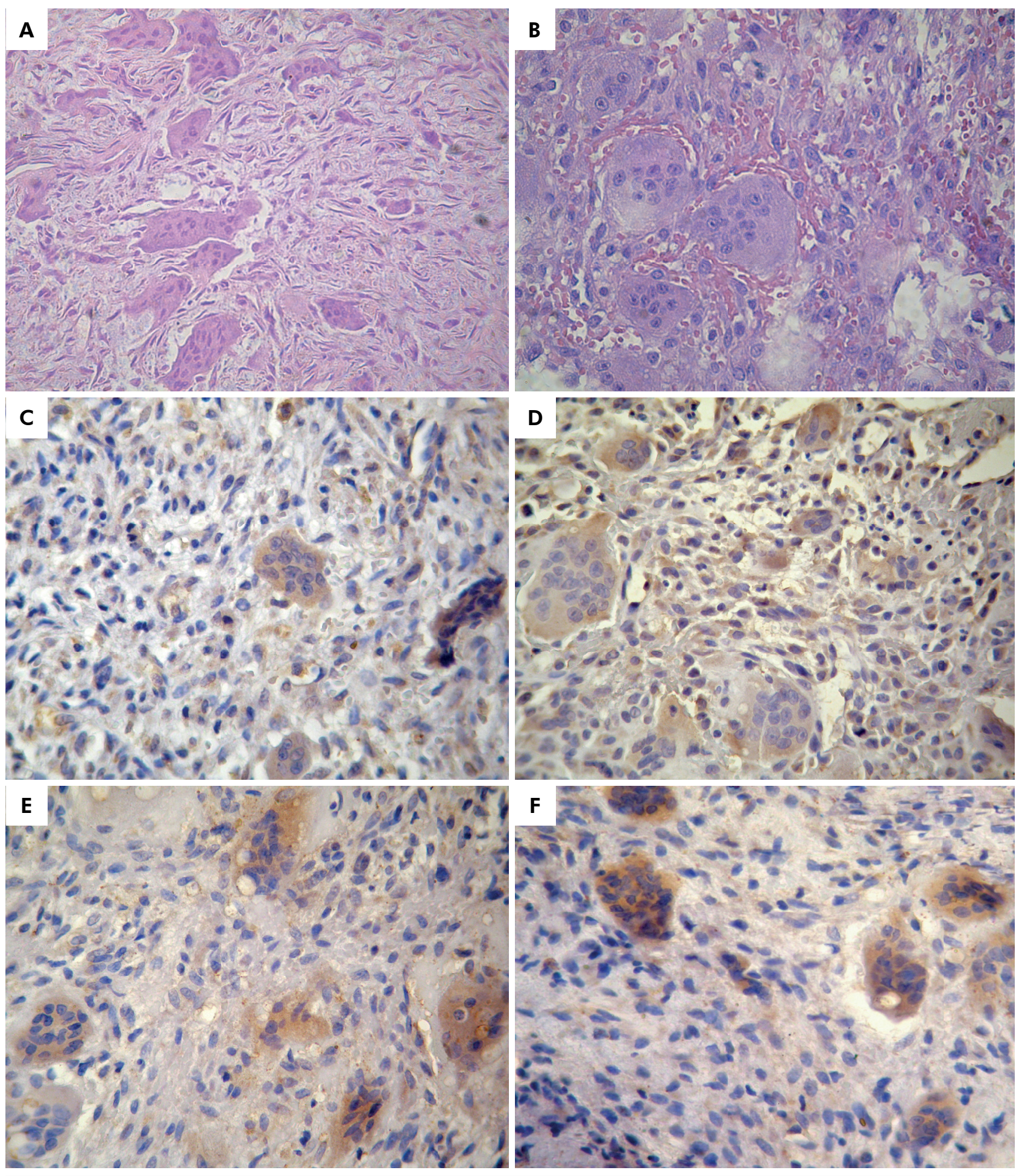

Figure. A. Photomicrograph showing high proliferation of multinucleated giant cells (MGCs) in peripheral giant cell lesion (Haematoxylin and eosin, original magnification 400x); B: Photomicrograph showing high proliferation of multinucleated giant cells (MGCs) in central giant cell lesion (Haematoxylin and eosin, original magnification 400x); C: Immunohistochemical expression of RANKL in MGCs and in mononuclear cells of peripheral giant cell lesion (Original magnification 400x); D: Immunohistochemical expression of RANKL in MGCs and in mononuclear cells of central giant cell lesion (Original magnification 400x); E: Immunohistochemical expression of osteoprotegerin in MGCs and in mononuclear cells of peripheral giant cell lesion (Original magnification 400x); F: Immunohistochemical expression of osteoprotegerin in MGCs and in mononuclear cells of central giant cell lesion (Original magnification 400x). 
Table 2. Comparison of multinucleated giant cells and immunoexpression of nuclear factor kappa-B ligand and osteoprotegerin in central and peripheral giant cell lesions according to recurrences.

\begin{tabular}{lccc}
\hline \multirow{2}{*}{ Variable } & Recurrent & Nonrecurrent & p-value \\
\cline { 2 - 3 } MGCs/mm & $(n=04)$ & $(n=36)$ & $0.013^{*}$ \\
MGC nuclei/mm & $68.75 \pm 20.27$ & $40.18 \pm 18.32$ & $0.032^{*}$ \\
RANKL (\%/area) & $399.75 \pm 84.88$ & $270.62 \pm 135.39$ & 0.680 \\
OPG (\%/area) & $8.12 \pm 5.83$ & $7.54 \pm 6.96$ & 0.191 \\
RANKL to OPG ratio & $7.38 \pm 1.75$ & $6.85 \pm 6.61$ & 0.394 \\
\hline
\end{tabular}

MGCs: Multinucleated giant cells; RANKL: Nuclear factor kappa-B ligand; OPG: Osteoprotegerin; *Mann-Whitney test.

\section{Discussion}

In the present study, we evaluated central and peripheral giant cell lesions. Both are benign lesions that affect gnathic bones and, despite presenting the same histological features, they have a different clinical behaviour. PGCL is more common than CGCL $^{1}$ and both can occur at any age. In our study, we observed a higher prevalence of both lesions in younger patients, consistent with other studies in the literature. ${ }^{2,7,16}$

Regarding sex distribution, PGCL, unlike CGCL, was more prevalent in males, which is in agreement with other studies. ${ }^{2,5,7,16} \mathrm{~A}$ higher prevalence of PGCL and CGCL was found in the mandible, as described by some authors. ${ }^{1,2,16,17}$ However, other studies have reported a higher prevalence of PGCL and CGCL in the maxilla. ${ }^{7,18}$

Microscopically, we found a higher number of MGC nuclei in CGCL when compared to PGCL, consistent with other studies. ${ }^{1,7}$ Although these lesions have similar microscopic features, they exhibit a different clinical behaviour. Many researchers have tried to explain these differences by cytomorphometric evaluation of the number of MGCs and of the number of nuclei per MGCs. Aghbali et al. ${ }^{7}$ analysed the microscopic aspects of these lesions, observing a mean number of nuclei per MGC of 9.54 in CGCL and of 8.58 in PGCL, while Florez-Moreno et al. ${ }^{1}$ found a higher number of nuclei within MGCs in CGCL than in PGCL.

Quantifying the MGCs present in these lesions has also been used as a tool for predicting their clinical behaviour, as performed in a study by Ficarra et al. ${ }^{19}$ These authors evaluated 32 cases of CGCL which were divided into two groups, non-aggressive and aggressive, and they observed a higher mean number of nuclei per MGC in the aggressive group. Clinical and radiographic criteria have been used to classify these lesions as aggressive or non-aggressive and to predict prognosis., ${ }^{7,15}$

Only few studies in the literature have evaluated the expression of RANKL and OPG in PGCL and CGCL. In our study, we observed higher expression of RANKL in CGCL than in PGCL as well as higher expression of RANKL and OPG in recurrent lesions. In a previous study, RANKL overexpression was higher in CGCL when compared to fibrous dysplasia (FO) and simple bone cysts (SBC). In the same study, FO and SBC presented a higher expression of OPG for the samples analysed. ${ }^{20}$ Another study evaluated the expression of RANKL and c-fos, a transcription factor that activates protein complex 1, essential for osteoclastogenesis, in CGCL, ${ }^{21}$ and both markers showed strong immunoreactivity. Fanourakis et al. ${ }^{22}$ evaluated the expression of RANKL and OPG in 22 cases of PGCL and observed high expression of these two markers.

Another report described higher expression of RANKL than of OPG in epithelial and mesenchymal cells of ameloblastic fibroma when compared to other odontogenic tumours with better clinical behaviour and fewer recurrences. ${ }^{11} \mathrm{~A}$ higher expression of RANKL was also described in bone metastasis from breast cancer and giant cell tumour, a locally aggressive benign osteolytic tumour with a high potential of recurrence. ${ }^{23,24}$ Investigations correlating RANKL expression with aggressiveness and recurrence potential in CGCL are scarce, but some case reports on CGCL with difficult management treated with denosumab, a RANKL inhibitor, demonstrated good results. ${ }^{25}$ 
The cytoplasmic and membrane-bound immunoreactivity detected in our samples was in accordance with that reported by other studies. ${ }^{11,13,20,26,27}$ RANKL and OPG are expressed by different cell types, including the monocyte/macrophage lineage, osteoclastic precursors, B and T cells, dendritic cells, and fibroblasts. ${ }^{11,27,28,29,30}$ Some reports on giant cell tumour have stated that RANKL overexpression in mononuclear cells could be the true neoplastic component of these lesions. ${ }^{24,31,32}$

Because CGCL is an osteolytic lesion, the samples were expected to have differentOPGimmunoexpression; however, no differences were observed between CGCL and PGCL. Furthermore, we observed a similar positive correlation between the RANKL to OPG ratio in both CGCL and PGCL. Differences in OPG functionality may depend on cell types. Osteoclasts undergo rapid apoptosis in the absence of trophic factors, such as M-CSF and RANKL. Extracellularly secreted OPG can indirectly induce apoptosis of the osteoclast itself by limiting the availability of RANKL that can be bound to RANK. ${ }^{33}$ Controversially, OPG secreted during osteoclastogenesis can bind to TRAIL, a member of the tumour necrosis factor family of cytokines, and

\section{References}

1. Flórez-Moreno GA, Henao-Ruiz M, Santa-Sáenz DM, Castañeda-Peláez DA, Tobón-Arroyave SI. Cytomorphometric and immunohistochemical comparison between central and peripheral giant cell lesions of the jaws. Oral Surg Oral Med Oral Pathol Oral Radiol Endod. 2008 May; 105(5):625-32. https://doi.org/10.1016/i.tripleo.2007.08.032

2. Motamedi MH, Eshghyar N, Jafari SM, Lassemi E, Navi F, Abbas FM et al. Peripheral and central giant cell granulomas of the jaws: a demographic study. Oral Surg Oral Med Oral Pathol Oral Radiol Endod. 2007 Jun;103(6):e39-43. https://doi.org/10.1016/i.tripleo.2006.12.022

3. Lester SR, Cordell KG, Rosebush MS, Palaiologou AA, Maney P. Peripheral giant cell granulomas: a series of 279 cases. Oral Surg Oral Med Oral Pathol Oral Radiol. 2014 Oct;118(4):47582. https://doi.org/10.1016/j.0000.2014.06.004

4. Lange J, kker HP, Berg H. Central giant cell granuloma of the jaw: a review of the literature with emphasis on therapy options. Oral Surg Oral Med Oral Pathol Oral Radiol Endod. 2007 Nov;104(5):603-15. https://doi.org/10.1016/i.tripleo.2007.04.003 inhibit cell death by apoptosis, which is opposite to the effects of the binding of OPG to RANKL. ${ }^{34,35}$

As limitations of this study, there were difficulties in the immunohistochemical evaluation of some cases due to the large deposition of hemosiderin. In addition, some patient clinical records were incomplete, meaning that correlations between some clinical and histological aspects could not be made.

Information on RANKL and OPG expression in bone pathologies has contributed to the better understanding of the mechanisms that regulate osteoclastogenesis in physiological and pathological states. Our findings showed high RANKL expression, which may explain the difference in clinical behaviour between CGCL and PGCL and their pathogenesis. However, further investigation is necessary to clarify and confirm these findings.

\section{Acknowledgements}

This study was supported by grants from the National Council for Scientific and Technological Development (process \# 458601/2014-4) and Coordination for the Improvement of Higher Education Personnel (Finance Code 001).
5. Reddy V, Saxena S, Aggarwal P, Sharma P, Reddy M. Incidence of central giant cell granuloma of the jaws with clinical and histological confirmation: an archival study in Northern India. Br J Oral Maxillofac Surg. 2012 Oct;50(7):668-72. https://doi.org/10.1016/i.bjoms.2011.10.015

6. Chuong R, Kaban LB, Kozakewich H, Perez-Atayde A. Central giant cell lesions of the jaws: a clinicopathologic study. J Oral Maxillofac Surg. 1986 Sep;44(9):708-13. https://doi.org/10.1016/0278-2391(86)90040-6

7. Aghbali A, Sina M, Vahid Pakdel SM, Emamverdizadeh P, Kouhsoltani M, Mahmoudi SM, et al. Correlation of histopathologic features with demographic, gross and radiographic findings in giant cell granulomas of the jaws. J Dent Res Dent Clin Dent Prospects. 2013;7(4):225-9.

8. Kumar VV, Krishanappa SJ, Prakash SG, Channabasaviah $\mathrm{GH}$, Murgod S, Pujari R et al. Quantification and correlation of angiogenesis with macrophages by histomorphometric method in central and peripheral giant cell granuloma: an immunohistochemical analysis. J Clin Diagn Res. 2016 Mar;10(3):ZC01-05. 
9. Souza PE, Mesquita RA, Gomez RS. Evaluation of p53, PCNA, Ki-67, MDM2 and AgNOR in oral peripheral and central giant cell lesions. Oral Dis. 2000 Jan;6(1):35-9. https://doi.org/10.1111/j.1601-0825.2000.tb00319.x

10. Tobón-Arroyave SI, Franco-González LM, Isaza-Guzmán DM, Floréz-Moreno GA, Bravo-Vásquez T, CastañedaPeláez DA et al. Immunohistochemical expression of RANK, GRalpha and CTR in central giant cell granuloma of the jaws. Oral Oncol. 2005 May;41(5):480-8. https://doi.org/10.1016/i.oraloncology.2004.11.006

11. Andrade FR, Sousa DP, Mendonça EF, Silva TA, Lara VS, Batista AC. Expression of bone resorption regulators (RANK, RANKL, and OPG) in odontogenic tumors. Oral Surg Oral Med Oral Pathol Oral Radiol Endod. 2008 Oct;106(4):54855. https://doi.org/10.1016/j.tripleo.2008.05.042

12. Siar $\mathrm{CH}$, Tsujigiwa $\mathrm{H}$, Ishak I, Hussin NM, Nagatsuka $\mathrm{H}, \mathrm{Ng}$ $\mathrm{KH}$. RANK, RANKL, and OPG in recurrent solid/multicystic ameloblastoma: their distribution patterns and biologic significance. Oral Surg Oral Med Oral Pathol Oral Radiol. 2015 Jan;119(1):83-91. https://doi.org/10.1016/j.000o.2014.09.017

13. Silva TA, Batista AC, Mendonça EF, Leles CR, Fukada S, Cunha FQ. Comparative expression of RANK, RANKL, and OPG in keratocystic odontogenic tumors, ameloblastomas, and dentigerous cysts. Oral Surg Oral Med Oral Pathol Oral Radiol Endod. 2008 Mar;105(3):333-41. https://doi.org/10.1016/i.tripleo.2007.06.009

14. Wada T, Nakashima T, Hiroshi N, Penninger JM. RANKL-RANK signaling in osteoclastogenesis and bone disease. Trends Mol Med. 2006 Jan;12(1):17-25. https://doi.org/10.1016/j.molmed.2005.11.007

15. Peacock ZS, Resnick CM, Susarla SM, Faquin WC, Rosenberg AE, Nielsen GP et al. Do histologic criteria predict biologic behavior of giant cell lesions? J Oral Maxillofac Surg. 2012 Nov;70(11):257380. https://doi.org/10.1016/i.joms.2011.12.005

16. Sun ZJ, Cai Y, Zwahlen RA, Zheng YF, Wang SP, Zhao YF. Central giant cell granuloma of the jaws: clinical and radiological evaluation of 22 cases. Skeletal Radiol. 2009 Sep;38(9):903-9. https://doi.org/10.1007/s00256-009-0740-8

17. Shadman N, Ebrahimi SF, Jafari S, Eslami M. Peripheral giant cell granuloma: a review of 123 cases. Dent Res J (Isfahan). 2009;6(1):47-50.

18. Boffano P, Benech R, Roccia F, Gallesio C, Garzaro $M$, Pecorari $G$. Review of peripheral giant cell granulomas. J Craniofac Surg. 2013 Nov;24(6):2206-8. https://doi.org/10.1097/SCS.0b013e31829a8316

19. Ficarra G, Kaban LB, Hansen LS. Central giant cell lesions of the mandible and maxilla: a clinicopathologic and cytometric study. Oral Surg Oral Med Oral Pathol. 1987 Jul;64(1):44-9. https://doi.org/10.1016/0030-4220(87)90115-0

20. Elias LS, Costa RF, Carvalho MA, Batista AC, Silva TA, Leles $C R$ et al. Markers of bone remodeling in neoplastic and bone-related lesions. Oral Surg Oral Med Oral Pathol Oral Radiol Endod. 2010 Nov;110(5):624-31. https://doi.org/10.1016/i.tripleo.2010.06.014
21. Ahmed AA, Dunlap C. Immunohistochemical detection of the receptor activator of nuclear factor Kappa B ligand and c-fos in giant cell granuloma. J Oral Maxillofac Pathol. 2016 Jan-Apr;20(1):47-50. https://doi.org/10.4103/0973-029X.180928

22. Fanourakis G, Lazaris AC, Krithinakis S, Tosios KI, Sklavounou $A$, Tseleni-Balafouta $S$. Expression of receptor activator of NF- $\kappa B$ ligand and osteoprotegerin in peripheral giant cell granulomas of the jaws. J Oral Pathol Med. 2010 Oct;39(9):687-9. https://doi.org/10.1111/j.1600-0714.2010.00924.x

23. Azim HA, Kamal NS, Azim HA Jr. Bone metastasis in breast cancer: the story of RANK-ligand. J Egypt Natl Canc Inst. 2012 Sep;24(3):107-14. https://doi.org/10.1016/i.jnci.2012.06.002

24. Huang L, Xu J, Wood DJ, Zheng MH. Gene expression of osteoprotegerin ligand, osteoprotegerin, and receptor activator of NF-kappaB in giant cell tumor of bone: possible involvement in tumor cell-induced osteoclastlike cell formation. Am J Pathol. 2000 Mar; 156(3):761-7. https://doi.org/10.1016/S0002-9440(10)64942-5

25. Gupta B, Stanton N, Coleman H, White C, Singh J. A novel approach to the management of a central giant cell granuloma with denosumab: A case report and review of current treatments. J Craniomaxillofac Surg. 2015 Sep;43(7):1127-32. https://doi.org/10.1016/i.jcms.2015.04.011

26. Matos FR, Moraes M. Silva EBN, Galvao HC, Freitas RA. Immunohistochemical detection of receptor activator nuclear kappaB ligand and osteoprotegerin in odontogenic cysts and tumors. J Oral Maxillofac Surg. 2013;71(11):1886-92. https://doi.org/10.1016/i.joms.2013.05.023

27. Chuang FH, Hsue SS, Wu CW, Chen YK. Immunohistochemical expression of RANKL, RANK, and OPG in human oral squamous cell carcinoma. J Oral Pathol Med. 2009 Nov;38(10):753-8. https://doi.org/10.1111/j.1600-0714.2009.00793.x

28. Hofbaver LC. Pathophysiology of RANK ligand (RANKL) and osteoprotegerin (OPG). Ann Endocrinol (Paris). 2006 Apr;67(2):139-41. https://doi.org/10.1016/S0003-4266(06)72569-0

29. Blair JM, Zheng Y, Dunstan CR. RANK ligand. Int J Biochem Cell Biol. 2007;39(6):1077-81. https://doi.org/10.1016/i.biocel.2006.11.008

30. Khosla S. Minireview: the OPG/RANKL/RANK system. Endocrinology. 2001 Dec;142(12):5050-5. https://doi.org/10.1210/endo.142.12.8536

31. Atkins GJ, Haynes DR, Graves SE, Evdokiou A, Hay $S$, Bouralexis $S$ et al. Expression of osteoclast differentiation signals by stromal elements of giant cell tumors. J Bone Miner Res. 2000 Apr;15(4):640-9. https://doi.org/10.1359/jbmr.2000.15.4.640

32. Branstetter DG, Nelson SD, Manivel JC, Blay JY, Chawla $\mathrm{S}$, Thomas DM et al. Denosumab induces tumor reduction and bone formation in patients with giant-cell tumor of bone. Clin Cancer Res. 2012 Aug;18(16):4415-24. https://doi.org/10.1158/1078-0432.CCR-12-0578 
- Immunohistochemical expression of RANKL in oral giant cell lesions is predictive of aggressiveness

33. Kang JH, Ko HM, Moon JS, Yoo HI, Jung JY, Kim MS et al. Osteoprotegerin expressed by osteoclasts: an autoregulator of osteoclastogenesis. J Dent Res. 2014 Nov;93(11):1116-23. https://doi.org/10.1177/0022034514552677

34. Truneh A, Sharma S, Silverman C, Khandekar S, Reddy $M P$, Deen KC, et al. Temperature-sensitive differential affinity of TRAIL for its receptors. DR5 is the highest affinity receptor. J Biol Chem. 2000 Jul;275(30):23319-25.

https://doi.org/10.1074/ibc.M910438199

35. Lane D, Matte I, Laplante C, Garde-Granger P, Rancourt C, Piché A. Osteoprotegerin (OPG) activates integrin, focal adhesion kinase (FAK), and Akt signaling in ovarian cancer cells to attenuate TRAIL-induced apoptosis. J Ovarian Res. 2013 Nov;6(1):82. https://doi.org/10.1186/1757-2215-6-82 